\title{
A hydrogel biosensor for high selective and sensitive detection of amyloid-beta oligomers
}

This article was published in the following Dove Press journal: International Journal of Nanomedicine

\author{
Liping Sun' \\ Yong Zhong' \\ Jie Gui' \\ Xianwu Wang' \\ Xiaorong Zhuang ${ }^{2}$ \\ Jian Weng'
}

'Key Laboratory of Biomedical Engineering of Fujian Province, Research Center of Biomedical Engineering of Xiamen, Department of Biomaterials, College of Materials, Xiamen University, ${ }^{2}$ Department of Neurology, The Affiliated Zhongshan Hospital of Xiamen University, Xiamen, People's Republic of China

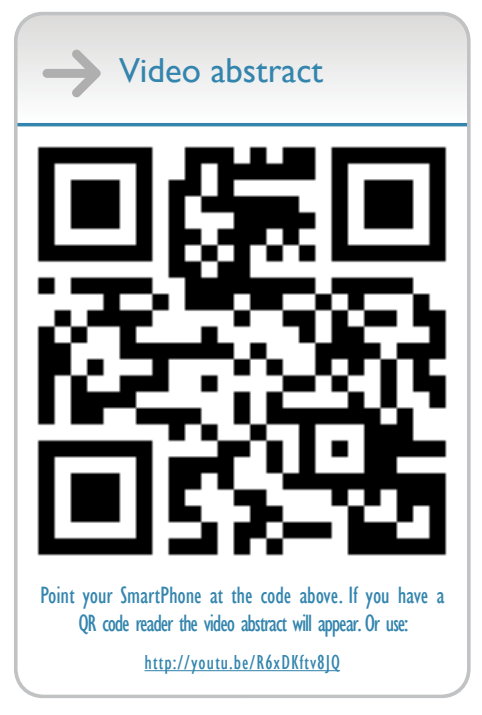

Correspondence: Liping Sun Key Laboratory of Biomedical Engineering of Fujian Province, Research Center of Biomedical Engineering of Xiamen, Department of Biomaterials, College of Materials, Siming Nan Road 422, Xiamen University, Xiamen 361005, People's Republic of China

Tel/fax +86592 2183181

Email sunliping@xmu.edu.cn
Background: Alzheimer's disease (AD) is a neurodegenerative disorder characterized by progressive cognitive and memory impairment. It is the most common neurological disease that causes dementia. Soluble amyloid-beta oligomers $(\mathrm{A} \beta \mathrm{O})$ in blood or cerebrospinal fluid (CSF) are the pathogenic biomarker correlated with AD.

Methods: A simple electrochemical biosensor using graphene oxide/gold nanoparticles (GNPs) hydrogel electrode was developed in this study. Thiolated cellular prion protein $\left(\operatorname{PrP}^{\mathrm{C}}\right)$ peptide probe was immobilized on GNPs of the hydrogel electrode to construct an A $\beta O$ biosensor. Electrochemical impedance spectroscopy was utilized for $\mathrm{A} \beta \mathrm{O}$ analysis.

Results: The specific binding between $\mathrm{A} \beta \mathrm{O}$ and $\mathrm{PrP}^{\mathrm{C}}$ probes on the hydrogel electrode resulted in an increase in the electron-transfer resistance. The biosensor showed high specificity and sensitivity for $A \beta O$ detection. It could selectively differentiate $A \beta O$ from amyloid-beta $(A \beta)$ monomers or fibrils. Meanwhile, it was highly sensitive to detect as low as $0.1 \mathrm{pM} \mathrm{A} \beta O$ in artificial CSF or blood plasma. The linear range for $\mathrm{A} \beta \mathrm{O}$ detection is from $0.1 \mathrm{pM}$ to $10 \mathrm{nM}$. Conclusion: This biosensor could be used as a cost-effective tool for early diagnosis of AD due to its high electrochemical performance and bionic structure.

Keywords: Alzheimer's disease, amyloid-beta oligomer, graphene, gold nanoparticles, biosensor

\section{Introduction}

Alzheimer's disease (AD) is a common neurodegenerative disorder in old people and the most common cause of dementia. The accumulation of beta-amyloid interferes with the synapse function and contributes to the damage of neurons. ${ }^{1}$ According to World Alzheimer Report 2016, there are 47.5 million people living with dementia in the world and 7.7 million new cases every year. The total estimated worldwide cost of dementia is 818 billion USD. ${ }^{2}$ New techniques for early diagnosis and prevention of $\mathrm{AD}$ are being developed to decrease the huge economic burden.

Misfolding and aggregation of amyloid-beta $(A \beta)$ is the potential pathological mechanism of $A D$. $A \beta$ monomers can be assembled into $A \beta$ oligomers $(A \beta O)$ and fibrils and then distributed into the cerebrospinal fluid (CSF) or blood circulation. $\mathrm{A} \beta \mathrm{O}$ are considered to be the most neurotoxic form and more closely correlated with the severity of $\mathrm{AD}$ than insoluble aggregates. ${ }^{3}$ The study of Gong et al shows that the concentration of $\mathrm{A} \beta \mathrm{O}$ was found to be up to 70 -fold higher in $\mathrm{AD}$ patients than that in nondemented controls. ${ }^{4}$ With regard to its close relationship with AD development, $\mathrm{A} \beta \mathrm{O}$ is considered as a core biomarker for $\mathrm{AD}$, especially in the early stage of $\mathrm{AD} .^{5}$

Current techniques for $\mathrm{A} \beta \mathrm{O}$ analysis can be classified as qualitative and quantitative methods. The qualitative methods, such as circular dichroism (CD) spectroscopy and Fourier-transform infrared spectroscopy (FTIR), are used to study protein 
conformational changes. ${ }^{6,7}$ Western blot is a semiquantitative method for special recognition of $\mathrm{A} \beta \mathrm{O} .{ }^{8,9}$ Examples of quantitative analysis are enzyme-linked immunosorbent assay (ELISA), ${ }^{10}$ fluorescent assays, ${ }^{11,12}$ surface-enhanced Raman spectroscopy, ${ }^{13}$ flow cytometry, ${ }^{14}$ surface plasmon resonance nanosensor, ${ }^{15}$ and so on. The abovementioned methods usually need expensive monoclonal antibodies, fluorescent dye, or sophisticated instruments. Also, the requirement of carcinogenic substrate for chemiluminescent detection and the time-consuming effort limits the applications of these methods. The sensitivities of these methods are between $10 \mathrm{pM}$ and $1.7 \mu \mathrm{M}^{10-15}$ They cannot meet clinical diagnostic requirements of the samples with low $A \beta$ concentrations because the concentration of $A \beta$ in the human plasma and CSF is in the range of 5.5-195 pM. ${ }^{16}$ Recently, electrochemical studies of $A \beta$ detection ${ }^{17-20}$ have drawn increasing attention for its low cost, simplicity, and high sensitivity. Most groups have used gold electrode to detect $\mathrm{A} \beta \mathrm{O}$. Zhou et al fabricated an antibody-aptamer sandwich on glassy carbon electrode for $\mathrm{A} \beta \mathrm{O}$ evaluation. ${ }^{21}$ The detection limit for $\mathrm{A} \beta \mathrm{O}$ detection of these electrochemical biosensors were from 0.5 to 500 pM. ${ }^{17-21}$ In this study, a novel A $\beta O$ biosensor made of graphene oxide (GO)/gold nanoparticles (GNPs) hydrogel was developed. Compared with traditional solid electrodes, soft graphene hydrogel electrodes have many advantages. The three-dimensional (3D) porous hydrogel allows fast penetration of biomolecules into the electrode and binding with the capture probes, while solid electrodes can only adsorb biomolecules on its outer surface. Thus, hydrogel electrode has much larger surface area than solid electrode. In addition, the bionic structure of hydrogel containing abundant water is more biocompatible than solid electrode. Moreover, the volume and shape of hydrogel electrode can be changed to adjust its conductivity. These properties make 3D graphene a perfect candidate as a high-performance electrode material for biosensing. ${ }^{22}$ In our previous studies, we have shown that GO hydrogel electrode is highly sensitive for DNA detection due to its bionic structure and tunable conductivity. ${ }^{23}$ In this study, a novel GO/GNPs composite hydrogel biosensor for $\mathrm{A} \beta \mathrm{O}$ detection was constructed. Our literature review shows that there is no study in which $\mathrm{GO} /$ GNPs have been used as hydrogel biosensors for protein biomarker detection. This label-free impedimetric biosensor has high selectivity and sensitivity of $\mathrm{A} \beta \mathrm{O}$ in artificial CSF and blood plasma, without capturing $A \beta$ monomers or fibrils. These features open a promising path toward the application of this type of biosensor as a new tool for early diagnosis of AD.

\section{Materials and methods Materials}

The natural graphite powder (320 mesh) was purchased from Tianjin Guangfu Chemical Agent Co., Ltd. (Tianjin, China). $\mathrm{KCl}, \mathrm{KH}_{2} \mathrm{PO}_{4}, \mathrm{MgCl}_{2}, \mathrm{MgSO}_{4}, \mathrm{CaCl}_{2}, \mathrm{NaNO}_{3}, \mathrm{KMnO}_{4}$, magnesium powder, and ammonium persulfate (APS) were purchased from Guoyao Co., Ltd (Shanghai, China). 1,1,1,3,3,3-Hexafluoro-2-propanol (HFIP), sodium borohydride $\left(\mathrm{NaBH}_{4}\right), \mathrm{H}_{2} \mathrm{SO}_{4}, \mathrm{HCl}$, nitric acid, hydrazine hydrate, ethanol, $\mathrm{NaHCO}_{3}, \mathrm{NaOH}, \mathrm{NaH}_{2} \mathrm{PO}_{4}, \mathrm{NaCl}$, and $\mathrm{Na}_{2} \mathrm{HPO}_{4}$ were obtained from Xilong Chemical (Guangzhou, China). Chloroauric acid $\left(\mathrm{HAuC1}_{4}\right)$ and glucose were purchased from Sigma-Aldrich Co. (St Louis, MO, USA). Protein marker, glycine, Tris (hydroxymethyl) aminomethane, $2 \times$ Native Loading buffer, and Coomassie brilliant blue stain were purchased from Sangon Biotech. Co. Ltd (Shanghai, China). Tetramethylethylenediamine (TEMED), 30\% acrylamide (Acr-Bis), $4 \times$ Tris $\mathrm{HCl}(\mathrm{pH} 6.8$ ), and $4 \times$ Tris $\mathrm{HCl}(\mathrm{pH} 8.8$ ) were from Beyotime Biotechnology (Shanghai, China). The cellular prion protein $\left(\mathrm{PrP}^{\mathrm{C}}\right)$ peptide probe was synthesized by Sangon. A mini-polyethylene glycol $\left(\mathrm{PEG}_{7}\right)$ spacer is positioned between mercaptopropionic acid residue and $\mathrm{PrP}^{\mathrm{C}}$ probe (Figure S1). A $\beta_{1-42}(96.7 \%$ ) was synthesized by GL Biochem Ltd. (Shanghai, China). The conical-bottom centrifuge tubes were purchased from Axygen Scientific Inc. (Silicon Valley, CA, USA). Blood samples from healthy volunteers were obtained from the affiliated Zhongshan Hospital of Xiamen University. Deionized water was used in all experiments.

\section{Methods}

\section{Preparation and characterization of GO and GO/GNPs hydrogel electrodes}

GO was synthesized from graphite by the modified Hummers' method. ${ }^{24,25} \mathrm{GO}$ hydrogel was prepared based on our previous work except that no fish sperm DNA was added. ${ }^{23} \mathrm{~A}$ total of $0.5 \mathrm{~mL}$ of $4.05 \mathrm{mg} / \mathrm{mL}$ GO was dropped into a $2 \mathrm{~mL}$ conicalbottom centrifuge tube, which was heated at $95^{\circ} \mathrm{C}$ for $1 \mathrm{~h}$ in a thermomixer and cooled down to room temperature to form GO hydrogel. Similarly, $4.05 \mathrm{mg} / \mathrm{mL}$ GO, $1.25 \mathrm{mM}$ $\mathrm{HAuCl}_{4}$, and $1.2 \mathrm{mM} \mathrm{NaBH}_{4}$ were thoroughly mixed in a centrifuge tube and then heated at $95^{\circ} \mathrm{C}$ for $1 \mathrm{~h}$ before cooling down to form GO/GNPs hydrogel. Following that, the lids of all tubes were removed and the bottoms were embedded with a copper wire (5 $\mathrm{cm}$ in length and $1 \mathrm{~mm}$ in diameter) to produce hydrogel electrodes.

$\mathrm{HAuCl}_{4}$ and $\mathrm{NaBH}_{4}$ were mixed with GO. After 10 min, $\mathrm{GO}$ and $\mathrm{GO} / \mathrm{GNPs}$ solution were deposited onto 400 mesh $\mathrm{Cu}$ grids coated with carbon film. The grids were dried at room temperature for 1 day. Transmission electron microscope 
(TEM) images were performed on a JEM2100 TEM (Hitachi Ltd., Tokyo, Japan). For Raman spectra and X-ray photoelectron spectroscopy (XPS), samples were deposited on silicon slices and were dried overnight at room temperature. Raman spectra were recorded on a Dilor SA LABRAM Raman spectrometer (Dilor SA, Lille, France). XPS spectra were measured on a Phi Quantum 2000 X-ray photoelectron spectrometer (PHI, Minneapolis, MN, USA). Diluted samples were cast onto fresh mica sheets. The mica sheets were then rinsed with water to remove salt residues and dried overnight at room temperature. The morphologies were characterized by the Nanoscope $\mathrm{V}$ multimode atomic force microscope (AFM; Veeco Instruments, New York, NY, USA) using the tapping mode. Zeta potentials were measured by a Malvern Nano-ZS (Malvern Instruments, Malvern, UK).

GO and GO/GNPs hydrogel were freeze-dried. The crystallographic structures were determined by a powder X-ray diffraction system (Philips PANalytical X'Pert) equipped with $\mathrm{Cu} \mathrm{K} \alpha$ radiation ( $\lambda=1,542 \AA$ ) (Ultima IV; Rigaku, Tokyo, Japan). The freeze-dried samples of GO and GO/GNPs hydrogel were placed on silicon slices and were coated with Au. Then, scanning electron microscope (SEM) images were performed on a LEO 1530 SEM (LEO, Oberkochen, Germany). Electrochemical impedance spectra (EIS) were detected using an electrochemical workstation, CHI660C (CH Instrument, Shanghai, China). The impedance analyses were conducted from $0.01 \mathrm{~Hz}$ to $10 \mathrm{kHz}$ at a modulation voltage of $5 \mathrm{mV}$ in phosphate-buffered saline (PBS; $137 \mathrm{mM} \mathrm{NaCl}, 1.68 \mathrm{mM} \mathrm{KCl}, 1.76 \mathrm{mM}$ $\mathrm{KH}_{2} \mathrm{PO}_{4}$, and $10 \mathrm{mM} \mathrm{Na}_{2} \mathrm{HPO}_{4}, \mathrm{pH} 7.4$ ).

\section{Preparation and characterization of the GO/GNPs-PrPC biosensor}

This hydrogel electrode was used as disposable biosensor because of strong binding between $\mathrm{A} \beta \mathrm{O}$ and $\mathrm{PrP}^{\mathrm{C}}$ probe. To decrease the stochastic error, we checked the resistance of all electrodes before immobilization of the $\mathrm{PrP}^{\mathrm{C}}$ probes. Only those electrodes with close resistance (relative deviation $<5 \%$ ) were used in following experiment. The $\mathrm{PrP}^{\mathrm{C}}$ probes were immobilized on the GO/GNPs hydrogel electrode to construct the GO/GNPs-PrPC $\mathrm{P}^{\mathrm{C}}$ biosensor. The details were described below. The $\operatorname{PrP}^{\mathrm{C}}$ peptide was suspended in 50\% acetic acid, since alkaline $\operatorname{PrP}^{\mathrm{C}}$ peptide was more soluble in acidic solution. A total of $200 \mu \mathrm{L}$ of $\operatorname{PrP}^{\mathrm{C}}$ peptide was added to the centrifuge tube with GO/GNPs hydrogel. After incubation, the solution was pipetted out and the hydrogel was rinsed with PBS for three times. The effects of the $\mathrm{PrP}^{\mathrm{C}}$ concentration $(0.01-0.5 \mathrm{mg} / \mathrm{mL})$ and incubation time $(5-30 \mathrm{~min})$ on the charge-transfer resistance $\left(R_{\mathrm{ct}}\right)$ were investigated by EIS.
Preparation and characterization of $A \beta$ monomers, oligomers, and fibrils

$\mathrm{A} \beta_{1-42}$ monomers and oligomers were prepared according to the procedures reported in the previous reports. ${ }^{17,26} \mathrm{The} A \beta_{1-42}$ peptides were suspended in $100 \%$ HFIP $(1 \mathrm{mg} / \mathrm{mL})$ and incubated under shaking at $37^{\circ} \mathrm{C}$ for $1.5 \mathrm{~h}$. The HFIP acts as a hydrogen-bond breaker to eliminate pre-existing structural inhomogeneity of $A \beta_{1-42} \cdot{ }^{27} \mathrm{HFIP}$ was evaporated under a gentle stream of nitrogen. Then, the HFIP-treated $A \beta_{1-42}$ was suspended in $100 \mu \mathrm{L}$ of $\mathrm{NaOH}(1 \mathrm{mM})$ and diluted in PBS to $100 \mu \mathrm{M}$ to obtain monomers. $\mathrm{A} \beta_{1-42}$ oligomers were formed by incubating monomers solution for $3 \mathrm{~h}$ at $4^{\circ} \mathrm{C}$ followed by centrifugation at $14,000 \times g$ for $15 \mathrm{~min}$ to remove any insoluble aggregates. The HFIP-treated $\mathrm{A} \beta_{1-42}$ was suspended in $\mathrm{HCl}(\mathrm{pH} 2)$ at $37^{\circ} \mathrm{C}$ for a day to obtain fibrils. ${ }^{28}$ The concentration of $\mathrm{A} \beta$ oligomers and fibrils was expressed as the concentration of monomeric $A \beta_{1-42}$ peptides (A $\beta$ monomer equivalent concentration). All solutions were immediately aliquoted and frozen at $-80^{\circ} \mathrm{C}$.

A total of $10 \mu \mathrm{L}$ of $5 \mu \mathrm{MA} \beta_{1-42}$ monomers, oligomers, or fibrils were cast onto fresh mica sheets. The mica sheets were then rinsed with water to remove salt residues and were dried overnight at room temperature. The morphologies of $\mathrm{A} \beta_{1-42}$ were characterized by the Nanoscope $V$ multimode AFM using the tapping mode.

$C D$ spectra of $A \beta$ peptides were measured on a Jasco J-810 spectropolarimeter (Tokyo, Japan) in the range of 195-265 nm. The optical chamber of CD spectrometer was deoxygenated with dry purified nitrogen for $30 \mathrm{~min}$ and was kept at the nitrogen atmosphere during experiments. Two scans were recorded and automatically averaged after subtracting the background spectrum of PBS. The contents of secondary structures ( $\alpha$-helix, $\beta$-sheet, and random coil) were determined by the Model JWSSE-480 Jasco Secondary Structure Estimation program based on Yang's reference CD spectra. ${ }^{29}$

\section{In vitro detection of $\mathrm{A} \beta \mathrm{O}$ by electrochemical impedance measurement}

Impedance measurements were carried out in PBS using an electrochemical workstation. A total of $5 \mathrm{mV}$ AC voltage amplitude and $0.1-10^{5} \mathrm{~Hz}$ voltage frequencies were applied. Artificial CSF $\left(\mathrm{NaCl} 124 \mathrm{mM}, \mathrm{KCl} 3 \mathrm{mM}, \mathrm{NaH}_{2} \mathrm{PO}_{4}\right.$ $1.25 \mathrm{mM}, \mathrm{NaHCO}_{3} 26 \mathrm{mM}, \mathrm{MgSO}_{4} 1.8 \mathrm{mM}, \mathrm{CaCl}_{2} 1.6 \mathrm{mM}$, and glucose $10 \mathrm{mM}, \mathrm{pH} 7.4$ ) was prepared according to previous method. ${ }^{30}$ Anticoagulated blood samples drawn from healthy subjects were centrifuged at $3,000 \times g$ at $4^{\circ} \mathrm{C}$ for $10 \mathrm{~min}$. The supernatants were collected as blood plasma, aliquoted, and stored at $-80^{\circ} \mathrm{C}$. $\mathrm{A} \beta \mathrm{O}$ was diluted in artificial 
CSF or blood plasma to obtain different concentrations (0.1 pM-1 $\mu \mathrm{M})$. Then, the $\operatorname{PrP}^{\mathrm{C}}$ immobilized hydrogel electrode was incubated with different concentrations of A $\beta O .200 \mu \mathrm{L}$ of $0.1 \mathrm{pM}-10 \mathrm{nM} \mathrm{A} \beta \mathrm{O}$ was dropped on the hydrogel and incubated for $30 \mathrm{~min}$ at $4^{\circ} \mathrm{C}$. Excess $\mathrm{A} \beta \mathrm{O}$ was removed by washing with $1 \mathrm{~mL}$ of PBS for three times. Each time, the hydrogel electrode was incubated in PBS for $5 \mathrm{~min}$. The selectivity of the biosensor was tested with $1 \mathrm{nM} \mathrm{A} \beta_{1-42}$ monomer, oligomer, and fibril in CSF.

\section{Ethics}

Ethical approval was given by the medical ethics committee of Xiamen University. Written informed consent was obtained from all of the blood donors.

\section{Results and discussion Principle of $A \beta O$ detection by GO/GNPs-PrPC biosensor}

Scheme 1 shows the principal of $\mathrm{A} \beta \mathrm{O}$ detection by $\mathrm{GO} /$ GNPs-PrP ${ }^{\mathrm{C}}$ biosensor. The GO/GNPs hydrogel is the working electrode. A platinum wire and an $\mathrm{Ag} / \mathrm{AgCl}$ electrode serve as the auxiliary and the reference electrodes, respectively (Scheme $1 \mathrm{~A}$ ). Thiolated $\mathrm{PrP}^{\mathrm{C}}$ probe is immobilized on GNPs of the hydrogel electrode through $\mathrm{Au}-\mathrm{S}$ bonding (Scheme $1 \mathrm{~B}$ ). $\mathrm{A} \mathrm{PEG}_{7}$ spacer is positioned between mercaptopropionic acid residue and $\operatorname{PrP}^{\mathrm{C}}$ probe to avoid nonspecific interactions between the electrode surface and $\mathrm{A} \beta$ peptides (Figure $\mathrm{S} 1$ ). The biosensor can specifically bind $\mathrm{A} \beta \mathrm{O}$ due to the high affinity of $\mathrm{PrP}^{\mathrm{C}}$ probe toward $\mathrm{A} \beta \mathrm{O}$ (Scheme 1C), which causes an increase in the electrontransfer resistance $\left(R_{\mathrm{ct}}\right)$ of GO/GNPs hydrogel electrode (Scheme 1D).

\section{Characterization of GO/GNPs hydrogel}

TEM image shows the sheet structure of GO (Figure 1A). GO/GNP is a TEM of hydrogel in which GNPs were grown on GO surface (Figures $1 \mathrm{~B}$ and $\mathrm{S} 2 \mathrm{~B}$ ). The average size of GNPs on GO sheet is $43 \mathrm{~nm}$ (Figure 1C). SEM photos show porous structure of both GO and GO/GNPs hydrogel (Figure S2A and B). Partially reduced GO sheets are locally hydrophobic, due to their restored conjugated domains and diminished oxygenated functionalities (confirmed by X-ray

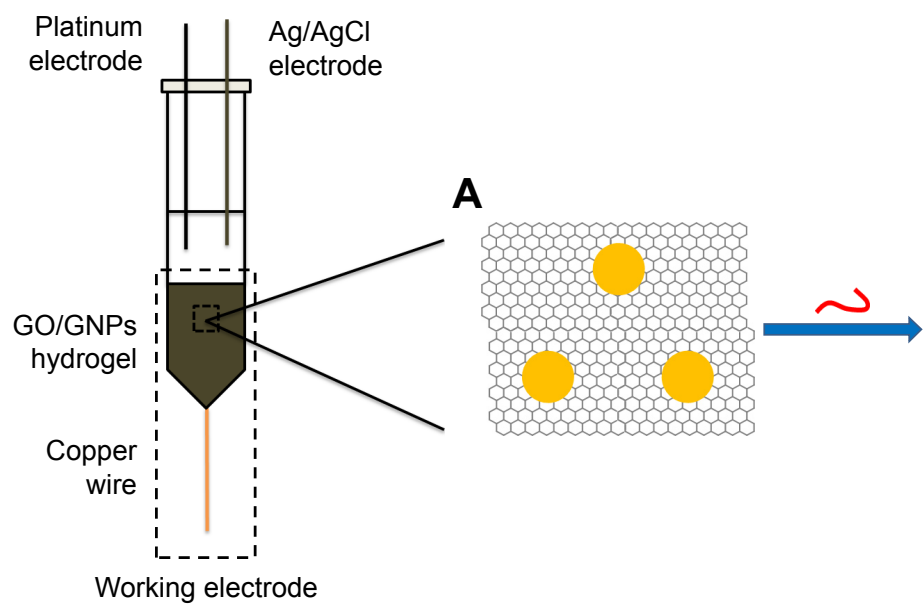

D

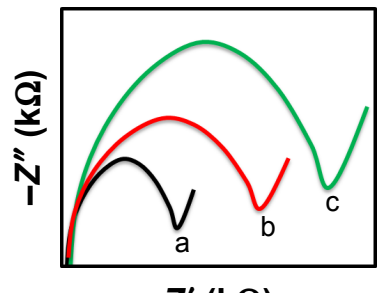

$Z^{\prime}(k \Omega)$

\begin{tabular}{|c|c|c|c|}
\hline GO sheets & GNPs & $A \beta_{1-42}$ oligomer & $\sim \mathrm{PrP}^{\mathrm{C}}$ probe \\
\hline
\end{tabular}

C
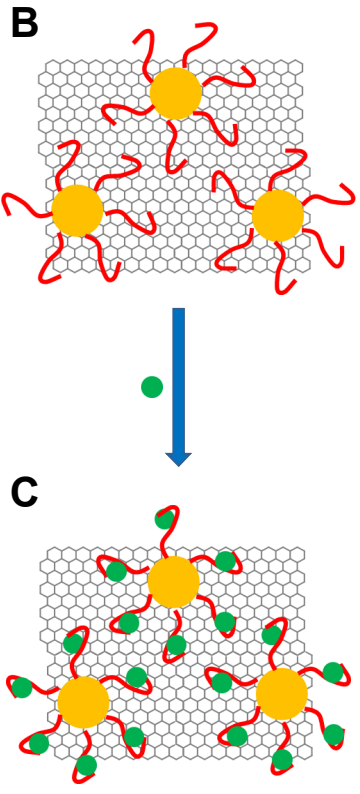

Scheme I The principle of $A \beta O$ detection by GO/GNPs-PrPC biosensor.

Notes: (A) GO/GNPs. (B) Immobilization of PrPC probe on GNPs. (C) Binding of A $\beta O$. (D) The charge transfer resistance $\left(R_{\mathrm{ct}}\right)$ of $(\mathrm{a})$ bare GO/GNPs electrode, (b) PrPC probe immobilized electrode, and (c) ABO captured GO/GNPs-PrPC biosensor.

Abbreviations: $A \beta$, amyloid-beta; $A \beta O, A \beta$ oligomers; GNPs, gold nanoparticles; $G O$, graphene oxide; PrPc, cellular prion protein. 
A

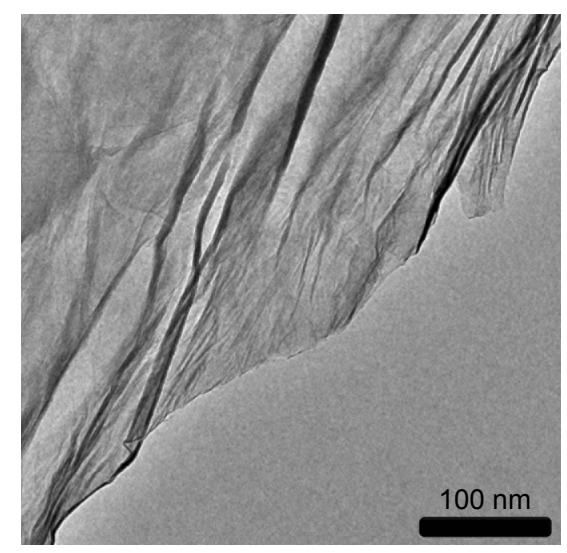

C

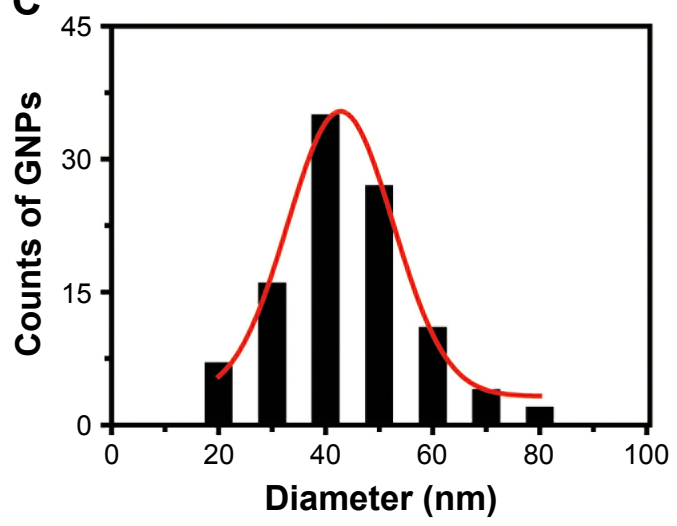

B

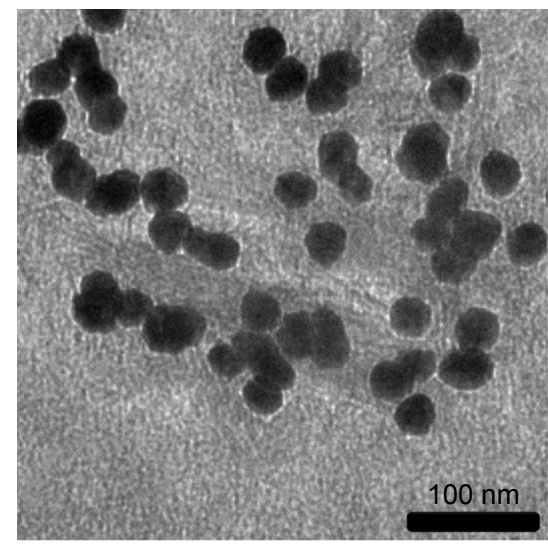

D

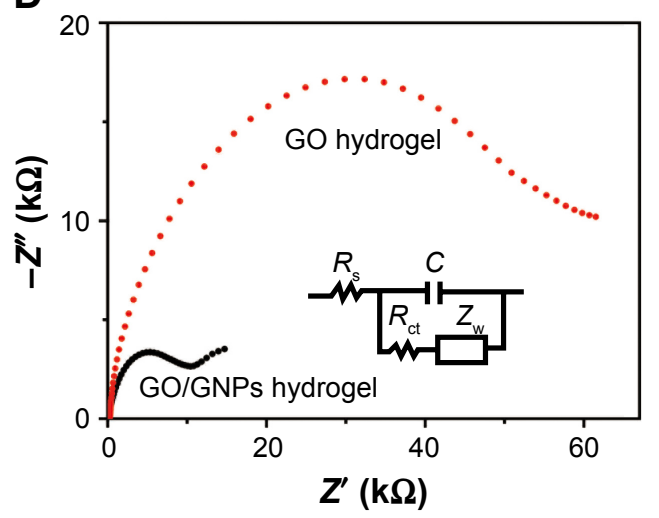

Figure I (A) TEM of GO. (B) TEM of GO/GNPs. (C) The size distribution of GNPs on the surface of GO/GNPs. A total of I00 gold nanoparticles on graphene surface were analyzed. Twenty, 40, 60, and $80 \mathrm{~nm}$ indicate the size distributions of I-20, $21-40,4 I-60$, and $6 I-80 \mathrm{~nm}$, respectively. (D) The charge transfer resistance ( $\left.R_{\mathrm{ct}}\right)$ of $\mathrm{GO}$ and GO/GNPs hydrogel. The insets show the Randles' equivalent circuit model.

Abbreviations: GNPs, gold nanoparticles; GO, graphene oxide; TEM, transmission electron microscope.

diffraction [XRD], Figure S3). The local hydrophobicity and $\pi-\pi$ interactions lead to $3 \mathrm{D}$ random stacking between some local regions of the graphene sheets and formation of the porous hydrogel. ${ }^{31}$ These pores help rapid penetration of biomolecules into the hydrogel. The interconnected porous network greatly enhances the electroactive surface areas for collecting signal. The AFM images show that the size of $\mathrm{GO}$ is $\sim 500 \mathrm{~nm}$, and the thickness is $\sim 0.9 \mathrm{~nm}$ (Figure $\mathrm{S} 4 \mathrm{~A}$ ), indicating a monolayer structure. ${ }^{32}$ The size and height of GNPs on GO/GNP hydrogel (Figure S4B) are consistent with those found by the TEM image (Figure 1B).

The XRD spectra show that GO hydrogel has a large interlayer distance $\left(7.25 \AA, 2 \theta=12.2^{\circ}\right.$ ) (Figure S3) due to the formation of hydroxyl, epoxy, and carboxyl groups, but the interlayer distance of GO/GNPs decreases to $3.63 \AA$ $\left(2 \theta=25.3^{\circ}\right)$ because of the removal of some oxygencontaining functional groups. ${ }^{33}$ The peaks at $38.02,44.18$, $64.67,77.68$, and $81.60^{\circ}$ were assigned to the respective (111), (200), (220), (311), and (222) reflections of a facecentered cubic (FCC) structure. We find this assignment consistent with the standard values of gold (JCPDS 04-0784), ${ }^{34}$ indicating the formation of GNPs. Full XPS spectrum of GO/GNPs shows an additional Au 4 f peak compared with GO (Figure S5A). Both GO and GO/GNPs hydrogel exhibit $\mathrm{C}-\mathrm{C}$ bond at $\sim 285 \mathrm{eV}, \mathrm{C}-\mathrm{O}$ at $287 \mathrm{eV}$, and $\mathrm{C}=\mathrm{O}$ at $288 \mathrm{eV}$ (Figure S5B and C), ${ }^{35}$ but the intensity of C-C bond of the $\mathrm{GO} / \mathrm{GNPs}$ hydrogel decreased significantly due to the reduction of GO. The Au $4 \mathrm{f}_{7 / 2}$ peak of GO/GNPs appears at a binding energy of $84.3 \mathrm{eV}$, and the $\mathrm{Au}_{5 / 2}$ peak is at $87.9 \mathrm{eV}$ (Figure S5D), confirming the formation of metallic gold. ${ }^{36}$ In conclusion, all the microscope images and spectra analyses indicate the formation of GNPs in the GO hydrogel.

EIS is a powerful tool for characterizing molecular interactions on the electrode surface and detecting small changes occurring at biosensor surfaces. Compared with other electrochemical methods, EIS has unique advantages, such as high sensitivity, signal quantification ease, and ability to separate the surface-binding events from the solution impedance. In addition, EIS is less destructive when measuring the biological interactions because it is performed in a very narrow range 
of small potentials. Therefore, EIS has been widely used to detect DNA, protein, or small molecules. ${ }^{7,37}$ The Randles equivalent circuit model was used in our system to measure the Nyquist plots (Figure 1D, inset). Typical EIS spectrum comprises a compressed semicircle in the high frequency region followed by a tail in the lower frequency region. The diameter of the semicircle corresponds to the electron-transfer resistance $\left(R_{\mathrm{ct}}\right)$. The high frequency region is dominated by the double layer capacitance $(C)$ and the electrolyte solution resistance $(R) . Z_{\mathrm{W}}$ represents the impedance caused by the Warburg diffusion element at lower frequencies. ${ }^{38}$ For very large $R_{\mathrm{ct}}$, the Warburg impedance is negligible. ${ }^{39}$ The semicircle diameter of the Nyquist plot of the GO/GNPs hydrogel decreased significantly, confirming that GNPs improved the conductivity of the hydrogel (Figure 1D).

The water content of GO/GNPs hydrogel was calculated by the following equation: water content $=$ (initial hydrogel weight - dried hydrogel weight)/initial hydrogel weight. The GO/GNPs hydrogel is abundant in water (96.19 wt\%), which provides a friendly interface for target biomolecule binding. The stability of GO/GNPs hydrogel stored at $4{ }^{\circ} \mathrm{C}$ was investigated by measuring the $R_{\mathrm{ct}}$ each day. The resistance did not show a significant change in 8 days (Figure S6), which means that the GO/GNPs hydrogel was stable in this period of time. The $R_{\mathrm{ct}}$ decreased gradually at the 9 th and 10 th days due to the collapse of hydrogel structure.

\section{Characterizations of $A \beta_{1-42}$ monomers, oligomers, and fibrils}

To investigate the morphologies of $A \beta_{1-42}$ monomers, oligomers, and fibrils, we made use of AFM imaging technique. Using this technique, we find the $A \beta_{1-42}$ monomers as unassembled structures with a typical size of $1 \mathrm{~nm}$ (Figure 2A). The oligomers show a spherical shape with a typical diameter of $4 \mathrm{~nm}$ (Figure $2 \mathrm{~B}$ ), whereas the $\mathrm{A} \beta_{1-42}$ fibrils extended over several microns with a height $\sim 3 \mathrm{~nm}$ (Figure 2C). Conformational studies were conducted by CD spectra. As shown in Figure S7, the monomers had a negative peak of $\sim 205 \mathrm{~nm}$, indicating the random coil structure. The $\mathrm{A} \beta_{1-42}$ oligomers had a wide band of $\sim 217 \mathrm{~nm}$, confirming the formation of $\beta$-sheet. Compared with the monomers, $A \beta_{1-42}$ oligomers and fibrils show a significant decrease of the random coil and an increase of the $\beta$-sheet structure (Table S1). These results indicate that $A \beta_{1-42}$ peptides underwent secondary structure transition from random-coil to $\beta$-sheet during aggregation process. ${ }^{40}$

\section{Construction of the GO/GNPs-PrPC biosensor}

In order to construct the GO/GNPs-PrPC biosensor, the $\mathrm{PrP}^{\mathrm{C}}$ probe was immobilized on the GO/GNPs hydrogel electrode. To find the optimal conditions for the biosensor, the effects of the incubation time of the $\operatorname{PrP}^{\mathrm{C}}$ probe with the GO/GNPs hydrogel electrode and the probe concentration on the resistance of the electrode were investigated. We found that $R_{\mathrm{ct}}$ gradually increased with time and $\mathrm{PrP}^{\mathrm{C}}$ probe concentration. $R_{\mathrm{ct}}$ reached the equilibrium at $15 \mathrm{~min}$ and $0.2 \mathrm{mg} / \mathrm{mL} \mathrm{PrP}^{\mathrm{C}}$ probe (Figure $\mathrm{S} 8$ ), indicating that the $\mathrm{PrP}^{\mathrm{C}}$ probes were saturated on the GO/GNPs hydrogel electrode. As a consequence, this incubation time and the probe concentration were used in the following experiments. In this study, the impedance measurements are not performed in the presence of a redox probe pair such as ferrocyanide/ferricyanide, because graphene/ GNPs complex material has good electrochemical activity.
A
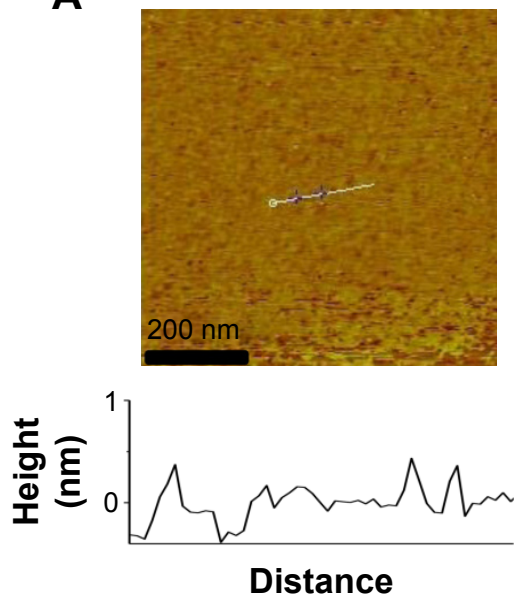

B
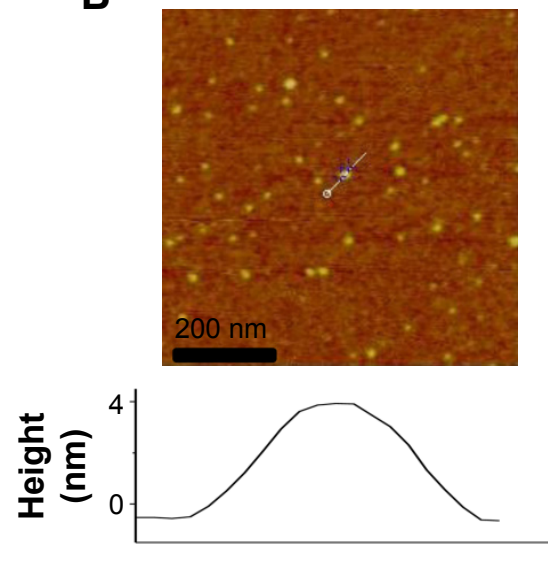

Distance
C
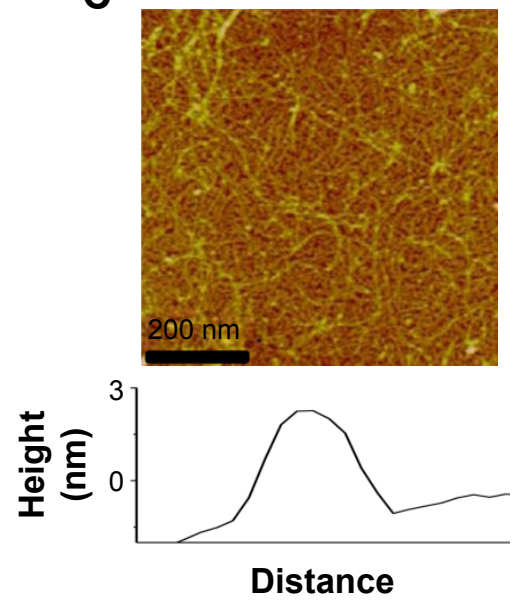

Figure 2 AFM of $A \beta_{1-42}$ monomers (A), oligomers (B), and fibrils (C). Abbreviations: $A \beta$, amyloid-beta; $A F M$, atomic force microscope. 
In addition, direct measurements of $\mathrm{A} \beta$ in PBS can avoid the denaturation of protein molecules and disturbance of the $\mathrm{PrP}^{\mathrm{C}}-\mathrm{A} \beta \mathrm{O}$ binding by ferrocyanide/ferricyanide.

\section{Electrochemical impedance assays for $\mathrm{A} \beta \mathrm{O}$ detection}

We prepared $A \beta O$ from synthetic $A \beta_{1-42}$ peptides. GO/GNPs$\mathrm{PrP}^{\mathrm{C}}$ biosensor was constructed by the immobilization of $\mathrm{PrP}^{\mathrm{C}}$ probe on the hydrogel electrode through $\mathrm{Au}-\mathrm{S}$ bonding. First, we investigated the selectivity of GO/GNPs-PrPC biosensor in the artificial CSF. The $R_{\mathrm{ct}}$ of GO/GNPs-PrPC increased in comparison with a bare GO/GNPs hydrogel electrode (Figure $3 \mathrm{~A}$, curves $\mathrm{a}$ and $\mathrm{b}$ ). $\mathrm{A} \beta \mathrm{O}$ binding resulted in a significant increase in the charge transfer resistance $R_{\mathrm{ct}}$ (Figure $3 \mathrm{~A}$, curve $\mathrm{d}$ ), because $\mathrm{A} \beta \mathrm{O}$ binding decreases the diffusion rate of $\mathrm{Na}^{+}$and $\mathrm{PO}_{4}^{3-}$ from PBS to the electrode interface.

On the other hand, no significant resistance changes were observed for $A \beta_{1-42}$ monomers or fibrils (Figure 3A, curves $\mathrm{c}$ and $\mathrm{e}) . \Delta R$ represents the electron-transfer resistance change of the $\mathrm{GO} / \mathrm{GNPs}-\mathrm{PrP}^{\mathrm{C}}$ biosensor after incubation with different $\mathrm{A} \beta \mathrm{O} . \Delta R$ for the $\mathrm{A} \beta_{1-42}$ oligomer is much higher than that for monomer and fibril (Figure 3B), indicating high selectivity of this biosensor. The good selectivity is based on the high affinity between $\operatorname{PrP}^{\mathrm{C}}$ probe and $\mathrm{A} \beta \mathrm{O}$. The cellular prion protein $\left(\mathrm{PrP}^{\mathrm{C}}\right)$ acts as $\mathrm{A} \beta \mathrm{O}$ receptor on neurons. $\mathrm{PrP}^{\mathrm{C}}$ probe is a short peptide with 16 amino acids (residues 95-110, THSQWNKPSKPKTNMK) located in the $\mathrm{N}$-terminal region of $\mathrm{PrP}^{\mathrm{C}}$. It has been confirmed that these residues are the core region for $A \beta_{1-42}$ oligomer binding. ${ }^{41}$ The dissociation constant for the $\mathrm{A} \beta \mathrm{O} / \mathrm{PrP}^{\mathrm{C}}$ interaction reaches $\mathrm{nM}$, and the binding is highly specific for $\mathrm{A} \beta$ oligomer but not for $\mathrm{A} \beta$ monomer and fibril. ${ }^{42,43}$ That is why we used $\operatorname{PrP}^{\mathrm{C}}$ $(95-110)$ probe as a receptor for $\mathrm{A} \beta \mathrm{O}$ detection. In order to

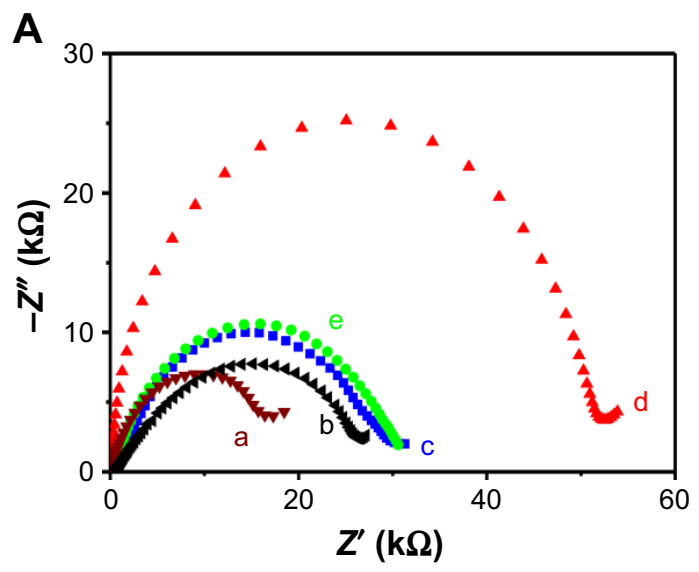

investigate whether the other existing components of blood, such as bovine serum albumin (BSA), glucose, and $\mathrm{NaCl}$, disturb $A \beta O$ detection, we checked the performance of the biosensor at different concentrations of the respective molecules and found no significant changes of the EIS spectra (Figure S9). These results confirmed that BSA, glucose, and $\mathrm{NaCl}$ do not disturb $\mathrm{A} \beta \mathrm{O}$ detection.

$\mathrm{A} \beta \mathrm{O}$ in CSF or blood are the pathogenic biomarker correlated with AD. ${ }^{44,45}$ Since lumbar puncture for CSF may cause cerebral and spinal herniation, headache, cranial neuropathies, nerve root irritation, back pain, and infectious and bleeding complications ${ }^{46}$ it is not accepted by many patients. Bearing in mind that the blood collected from human represents real condition of clinical samples, $\mathrm{A} \beta \mathrm{O}$ analysis in blood plasma would be of great value for wider diagnostic monitoring. In this study, $\mathrm{A} \beta \mathrm{O}$ were either diluted in artificial CSF or blood plasma to obtain different concentrations of $A \beta O$. The sensitivity of the GO/GNPs-PrPC biosensor for $\mathrm{A} \beta \mathrm{O}$ detection was investigated in this study. $R_{\mathrm{ct}}$ increased gradually upon increasing concentrations of $\mathrm{A} \beta \mathrm{O}$ (Figure $4 \mathrm{~A}$ and $\mathrm{C}$ ). The limit of detection reached at $0.1 \mathrm{pM}$, which is much lower than the low limit of the $A \beta_{1-42}$ concentration in CSF or blood plasma $(5.5 \mathrm{pM}) .{ }^{16} \Delta R$ showed a linear correlation with the $\mathrm{A} \beta \mathrm{O}$ concentrations (-log scale) (Figure 4B and D), and the linear response of the sensor lies in a wide range of $A \beta O$ concentrations $(0.1 \mathrm{pM}$ to $10 \mathrm{nM})$. The detection limit of our biosensor is lower than that of the other electrochemical or spectrometric methods for $\mathrm{A} \beta \mathrm{O}$ detection based on $\operatorname{PrP}^{\mathrm{C}}$ probe (Table S2) due to the following possible reasons: first, EIS is a powerful electrochemical technology for the detection of small changes occurring at biosensor surfaces. Second, the bionic structure of the soft hydrogel with abundant water provides a friendly interface

\section{B}

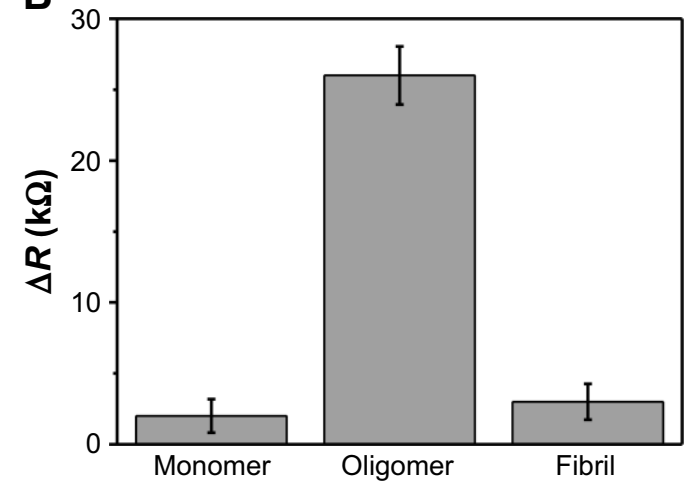

Figure 3 (A) The impedance spectra of the bare GO/GNPs hydrogel electrode (a) and the GO/GNPs-PrPC biosensor (b). The GO/GNPs-PrPC biosensor was used to differentiate I nM A $\beta_{1-42}$ monomer (c), oligomer (d), and fibril (e) in CSF. (B) $\Delta R$ for $A \beta_{1-42}$ monomer, oligomer, and fibril detection. Abbreviations: $A \beta$, amyloid-beta; CSF, cerebrospinal fluid; GNPs, gold nanoparticles; GO, graphene oxide; PrPC, cellular prion protein. 
A

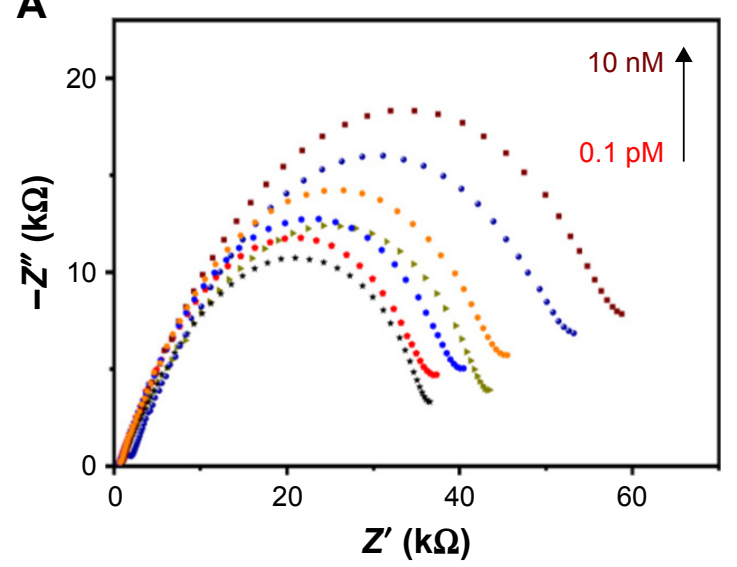

C

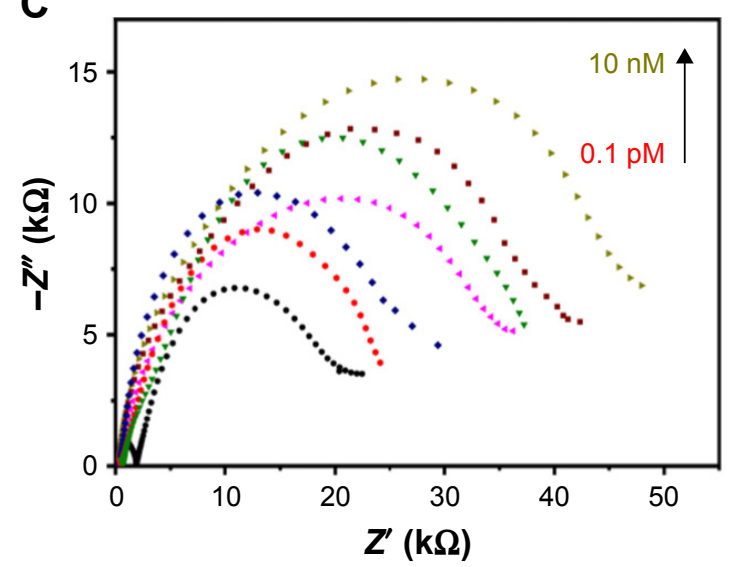

B

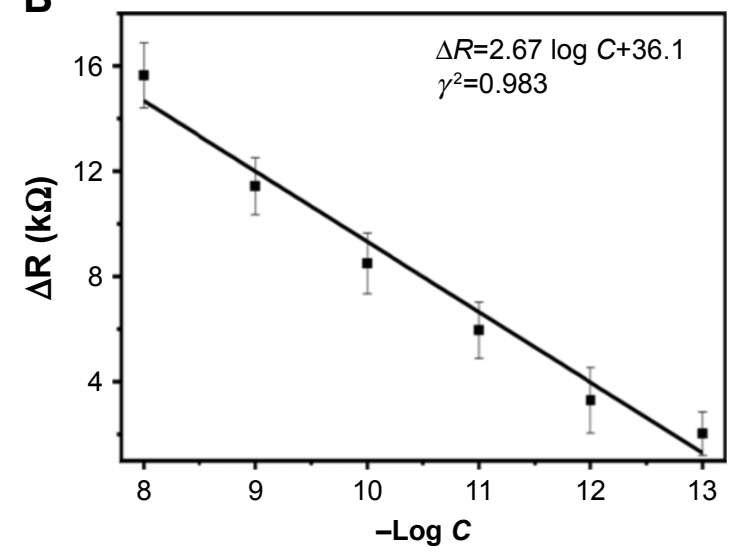

$\mathbf{D}$

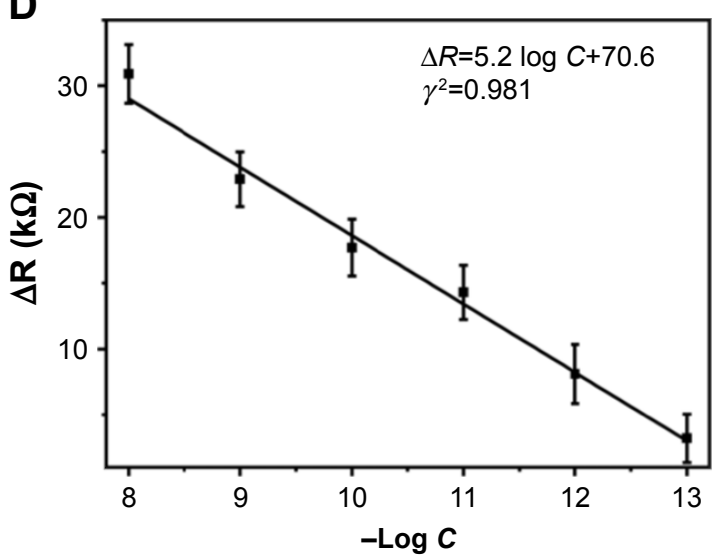

Figure 4 (A) The impedance spectra of the GO/GNPs-PrPC biosensor (black curve) and its response to CSF A $B O$. (B) The calibration plot of $\triangle R$ for CSF A $\beta O$ detection. (C) The impedance spectra of the GO/GNPs-PrPC biosensor (black curve) and its response to blood plasma $A \beta O$. (D) The calibration plot of $\Delta R$ for blood plasma $A \beta O$ detection. The error bars represent the standard deviation from the average of three independent measurements by three biosensors. $\Delta R$ : Charge transfer resistance $\left(R_{\mathrm{ct}}\right)$ change after binding with $\mathrm{A} \beta \mathrm{O}$. The colored lines represent 0.1 pM, I pM, 10 pM, 100 pM, I nM and $10 \mathrm{nM} \mathrm{A} \beta \mathrm{O}$, respectively.

Abbreviations: $A \beta O$, amyloid-beta oligomers; CSF, cerebrospinal fluid; GNPs, gold nanoparticles; GO, graphene oxide; PrPC, cellular prion protein.

for target biomolecules binding. Moreover, the intermediate conductivity of GO hydrogel is sensitive to the change of resistance introduced by trace amount of molecules binding on the surface of electrode. ${ }^{23}$ In addition, the 3D porous structure of hydrogel has enormous space and allows rapid penetration of biomolecules into the electrode, which benefits the adsorption and binding of $\mathrm{A} \beta \mathrm{O}$.

\section{Conclusion}

In this study, a GO/GNPs-PrPC hydrogel biosensor for specific and sensitive $\mathrm{A} \beta \mathrm{O}$ detection was presented based on EIS assay. The unique electrochemical property of GO/GNPs hydrogel electrode and the specific interaction of $\operatorname{PrP}^{\mathrm{C}}$ with $\mathrm{A} \beta \mathrm{O}$ result in powerful performance of this biosensor. It can selectively differentiate $\mathrm{A} \beta \mathrm{O}$ from $\mathrm{A} \beta$ monomers or fibrils. Meanwhile, it is highly sensitive to detect as low as $0.1 \mathrm{pM}$ $\mathrm{A} \beta \mathrm{O}$ in CSF or blood plasma. This biosensor can be used as a convenient tool for early diagnosis of AD. The strategy in this work may also present a general method for other protein assays. Quantitative determination of other target proteins can be achieved by coupling their corresponding peptide or aptamer probes in the GO/GNPs hydrogel.

\section{Acknowledgments}

This work is supported by the National Natural Science Foundation of China (81571764 and 31371005 ). We thank the visiting scholar, Professor RI Ristic from the University of Oxford, UK, for language correction.

\section{Author contributions}

Liping Sun designed the study. Yong Zhong and Jie Gui performed the experiments. All authors contributed toward data analysis, drafting and critically revising the paper, gave final approval of the version to be published, and agree to be accountable for all aspects of the work.

\section{Disclosure}

The authors report no conflicts of interest in this work. 


\section{References}

1. Alzheimer's Association. 2016 Alzheimer's disease facts and figures. Alzheimers Dement. 2016;12(4):459-509.

2. Prince M, Comas-Herrera A, Knapp M, Guerchet M, Karagiannidou M. World Alzheimer Report 2016: Improving Healthcare for People Living with Dementia: Coverage, Quality and Costs Now and in the Future. London: Alzheimer's Disease International; 2016.

3. Bieschke J, Herbst M, Wiglenda T, et al. Small-molecule conversion of toxic oligomers to nontoxic $\beta$-sheet-rich amyloid fibrils. Nat Chem Biol. 2012;8(1):93-101.

4. Gong Y, Chang L, Viola KL, et al. Alzheimer's disease-affected brain: presence of oligomeric A $\beta$ ligands (ADDLs) suggests a molecular basis for reversible memory loss. Proc Natl Acad Sci U S A. 2003;100(18): 10417-10422.

5. Blennow K, Hampel H, Weiner M, Zetterberg H. Cerebrospinal fluid and plasma biomarkers in Alzheimer disease. Nat Rev Neurol. 2010;6(3):131-144.

6. Younan ND, Sarell CJ, Davies P, Brown DR, Viles JH. The cellular prion protein traps Alzheimer's $\mathrm{A} \beta$ in an oligomeric form and disassembles amyloid fibers. FASEB J. 2013;27(5):1847-1858.

7. Veloso A, Kerman K. Advances in electrochemical detection for study of neurodegenerative disorders. Anal Bioanal Chem. 2013;405(17): $5725-5741$.

8. Stine WB, Dahlgren KN, Krafft GA, LaDu MJ. In vitro characterization of conditions for amyloid- $\beta$ peptide oligomerization and fibrillogenesis. J Biol Chem. 2003;278(13):11612-11622.

9. Haass C, Selkoe DJ. Soluble protein oligomers in neurodegeneration: lessons from the Alzheimer's amyloid $\beta$-peptide. Nat Rev Mol Cell Biol. 2007;8(2):101-112.

10. Bruggink KA, Jongbloed W, Biemans EALM, et al. Amyloid- $\beta$ oligomer detection by ELISA in cerebrospinal fluid and brain tissue. Anal Biochem. 2013;433(2):112-120.

11. Lv G, Sun A, Wei P, Zhang N, Lan H, Yi T. A spiropyran-based fluorescent probe for the specific detection of $\beta$-amyloid peptide oligomers in Alzheimer's disease. Chem Commun. 2016;52:8865-8868.

12. Xia N, Zhou B, Huang N, Jiang M, Zhang J, Liu L. Visual and fluorescent assays for selective detection of beta-amyloid oligomers based on the inner filter effect of gold nanoparticles on the fluorescence of CdTe quantum dots. Biosens Bioelectron. 2016;85:625-632.

13. Voiciuk V, Valincius G, Budvytytė R, Matijoška A, Matulaitienė I, Niaura G. Surface-enhanced Raman spectroscopy for detection of toxic amyloid $\beta$ oligomers adsorbed on self-assembled monolayers. Spectrochim Acta A. 2012;95:526-532.

14. Santos AN, Torkler S, Nowak D, et al. Detection of amyloid- $\beta$ oligomers in human cerebrospinal fluid by flow cytometry and fluorescence resonance energy transfer. J Alzheimers Dis. 2007;11(1):117-125.

15. Haes AJ, Chang L, Klein WL, Van Duyne RP. Detection of a biomarker for Alzheimer's disease from synthetic and clinical samples using a nanoscale optical biosensor. J Am Chem Soc. 2005;127(7):2264-2271.

16. Mehta PD, Pirttilä T, Mehta SP, Sersen EA, Aisen PS, Wisniewski HM. Plasma and cerebrospinal fluid levels of amyloid $\beta$ proteins 1-40 and 1-42 in Alzheimer disease. Arch Neurol. 2000;57(1):100-105.

17. Li H, Xie H, Cao Y, Ding X, Yin Y, Li G. A general way to assay protein by coupling peptide with signal reporter via supermolecule formation. Anal Chem. 2013;85(2):1047-1052.

18. Rushworth JV, Ahmed A, Griffiths HH, Pollock NM, Hooper NM, Millner PA. A label-free electrical impedimetric biosensor for the specific detection of Alzheimer's amyloid-beta oligomers. Biosens Bioelectron. 2014;56:83-90.

19. Xia N, Wang X, Zhou B, Wu Y, Mao W, Liu L. Electrochemical detection of amyloid- $\beta$ oligomers based on the signal amplification of a network of silver nanoparticles. ACS Appl Mater Interfaces. 2016;8(30):19303-19311.

20. Xing Y, Feng XZ, Zhang L, Hou J, Han GC, Chen Z. A sensitive and selective electrochemical biosensor for the determination of betaamyloid oligomer by inhibiting the peptide-triggered in situ assembly of silver nanoparticles. Int J Nanomedicine. 2017;12:3171-3179.
21. Zhou Y, Zhang H, Liu L, et al. Fabrication of an antibody-aptamer sandwich assay for electrochemical evaluation of levels of beta-amyloid oligomers. Sci Rep. 2016;6:35186.

22. Qiu HJ, Guan Y, Luo P, Wang Y. Recent advance in fabricating monolithic 3D porous graphene and their applications in biosensing and biofuel cells. Biosens Bioelectron. 2017;89(pt 1):85-95.

23. Sun LP, Hu N, Peng J, Chen LY, Weng J. Ultrasensitive detection of mitochondrial DNA mutation by graphene oxide/DNA hydrogel electrode. Adv Funct Mater. 2014;24(44):6905-6913.

24. Botas C, Álvarez P, Blanco P, et al. Graphene materials with different structures prepared from the same graphite by the Hummers and Brodie methods. Carbon N Y. 2013;65:156-164.

25. Chen J, Li Y, Huang L, Li C, Shi G. High-yield preparation of graphene oxide from small graphite flakes via an improved Hummers method with a simple purification process. Carbon N Y. 2015;81:826-834.

26. Barghorn S, Nimmrich V, Striebinger A, et al. Globular amyloid $\beta$-peptide 1-42 oligomer - a homogenous and stable neuropathological protein in Alzheimer's disease. J Neurochem. 2005;95(3):834-847.

27. Ahmed M, Davis J, Aucoin D, et al. Structural conversion of neurotoxic amyloid- $\beta 1-42$ oligomers to fibrils. Nat Struct Mol Biol. 2010;17(5): 561-567.

28. Sheikh AM, Nagai A. Lysophosphatidylcholine modulates fibril formation of amyloid beta peptide. FEBS J. 2011;278(4):634-642.

29. Yang JT, Wu CSC, Martinez HM. In: Hirs CHW, Timache VSN, editors. Methods in Enzymology. Vol. 130. Orlando: Park K Academic Press; 1986:208-269.

30. Gaub P, Léon A, Gibon J, et al. proBDNF: a new tool for the analysis of pro-brain derived neurotrophic factor receptor signaling and cell biology. PLoS One. 2016;11(3):e0150601.

31. Xu Y, Sheng K, Li C, Shi G. Self-assembled graphene hydrogel via a one-step hydrothermal process. ACS Nano. 2010;4(7):4324-4330.

32. Kim JW, Kang D, Kim TH, et al. Mosaic-like monolayer of graphene oxide sheets decorated with tetrabutylammonium ions. ACS Nano. 2013;7(9):8082-8088.

33. Fan Z, Wang K, Wei T, Yan J, Song L, Shao B. An environmentally friendly and efficient route for the reduction of graphene oxide by aluminum powder. Carbon N Y. 2010;48(5):1686-1689.

34. Zhang N, Qiu H, Liu Y, et al. Fabrication of gold nanoparticle/graphene oxide nanocomposites and their excellent catalytic performance. J Mater Chem. 2011;21:11080-11083.

35. Cittadini M, Bersani M, Perrozzi F, Ottaviano L, Wlodarski W, Martucci A. Graphene oxide coupled with gold nanoparticles for localized surface plasmon resonance based gas sensor. Carbon N Y. 2014;69: 452-459.

36. Li J, Han Q, Wang X, et al. Reduced aggregation and cytotoxicity of amyloid peptides by graphene oxide/gold nanocomposites prepared by pulsed laser ablation in water. Small. 2014;10(21):4386-4394.

37. Bogomolova A, Komarova E, Reber K, et al. Challenges of electrochemical impedance spectroscopy in protein biosensing. Anal Chem. 2009;81(10):3944-3949.

38. Lisdat F, Schäfer D. The use of electrochemical impedance spectroscopy for biosensing. Anal Bioanal Chem. 2008;391(5):1555.

39. Bard AJ, Faulkner LR. Chapter 10. Techniques based on concepts of impedance. In: Allen JB, Larry R, editors. Electrochemical Methods, Fundamentals and Applications. Second ed. New York: John Wiley \& Sons; 2001:368-387.

40. Fezoui Y, Teplow DB. Kinetic studies of amyloid $\beta$-protein fibril assembly: differential effects of $\alpha$-helix stabilization. J Biol Chem. 2002; 277(40):36948-36954.

41. Laurén J, Gimbel DA, Nygaard HB, Gilbert JW, Strittmatter SM. Cellular prion protein mediates impairment of synaptic plasticity by amyloid- $\beta$ oligomers. Nature. 2009;457(7233):1128-1132.

42. Fluharty BR, Biasini E, Stravalaci M, et al. An N-terminal fragment of the prion protein binds to amyloid- $\beta$ oligomers and inhibits their neurotoxicity in vivo. J Biol Chem. 2013;288(11):7857-7866.

43. Freir DB, Nicoll AJ, Klyubin I, et al. Interaction between prion protein and toxic amyloid $\beta$ assemblies can be therapeutically targeted at multiple sites. Nat Commun. 2011;2:336. 
44. Fukumoto H, Tokuda T, Kasai T, et al. High-molecular-weight $\beta$-amyloid oligomers are elevated in cerebrospinal fluid of Alzheimer patients. FASEB J. 2010;24(8):2716-2726.

45. Doecke JD, Laws SM, Faux NG, et al; Alzheimer's Disease Neuroimaging Initiative; Australian Imaging Biomarker and Lifestyle Research Group. Blood-based protein biomarkers for diagnosis of Alzheimer disease. Arch Neurol. 2012;69(10):1318-1325.
46. Evans RW. Complications of lumbar puncture. Neurol Clin. 1998;16(1): 83-105. 


\section{Supplementary materials}<smiles>CC(C)(COCCOCC(=O)NC(C)(C)NOS(=O)(=O)O[Na])NC(=O)CCS</smiles>

Figure SI The HS-PEG $-\mathrm{PrPC}$ probe.
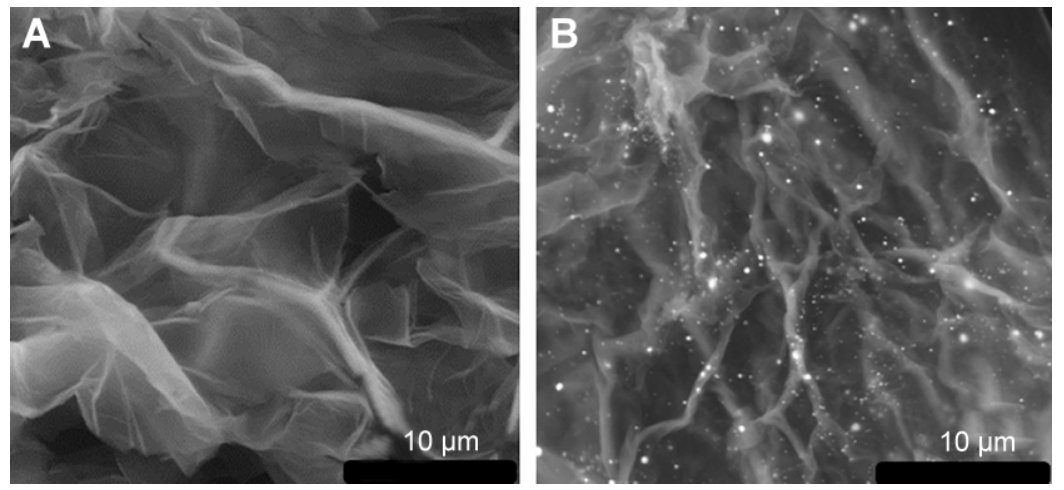

Figure S2 SEM images of GO (A) and GO/GNPs hydrogel (B).

Abbreviations: GNPs, gold nanoparticles; GO, graphene oxide; SEM, scanning electron microscope.

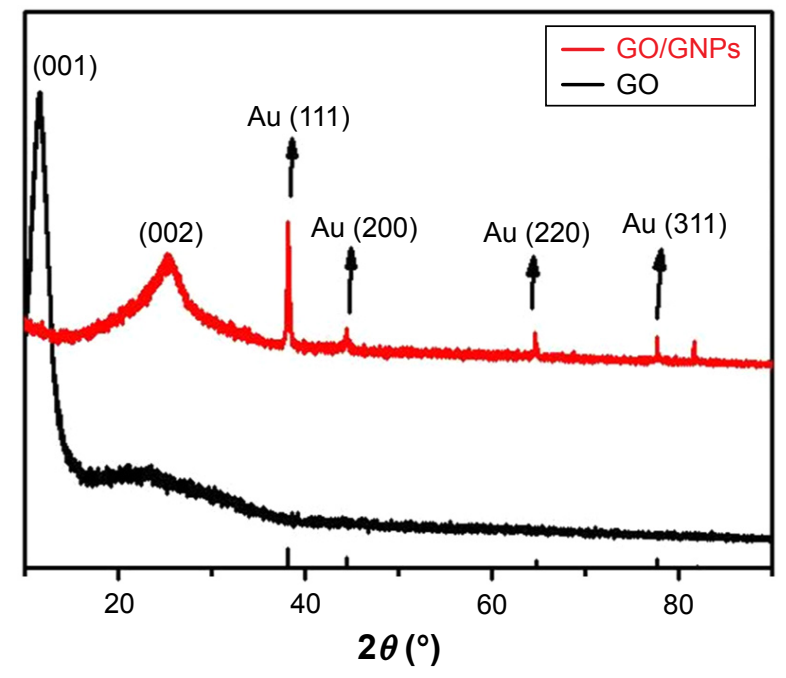

Figure S3 XRD spectra of GO and GO/GNPs hydrogel.

Abbreviations: GNPs, gold nanoparticles; GO, graphene oxide; XRD, X-ray diffraction. 
A
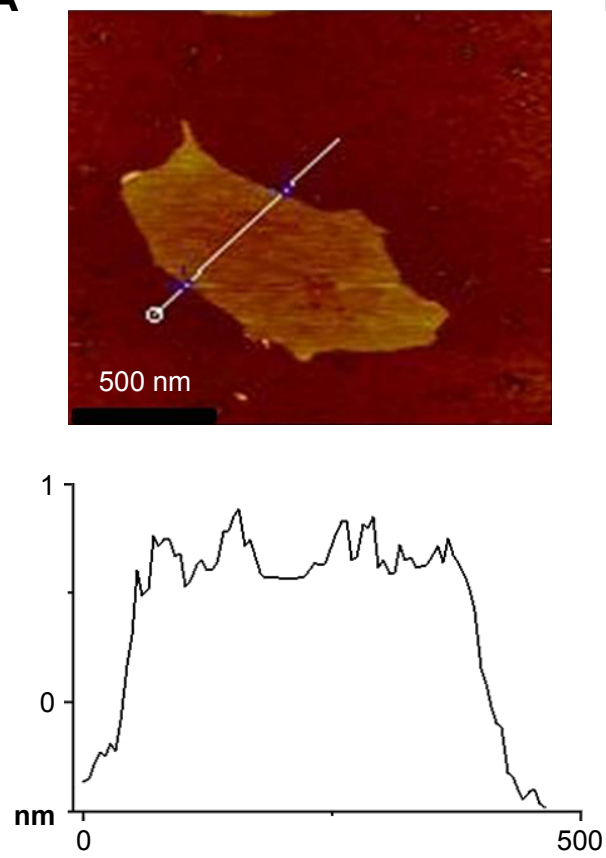

B
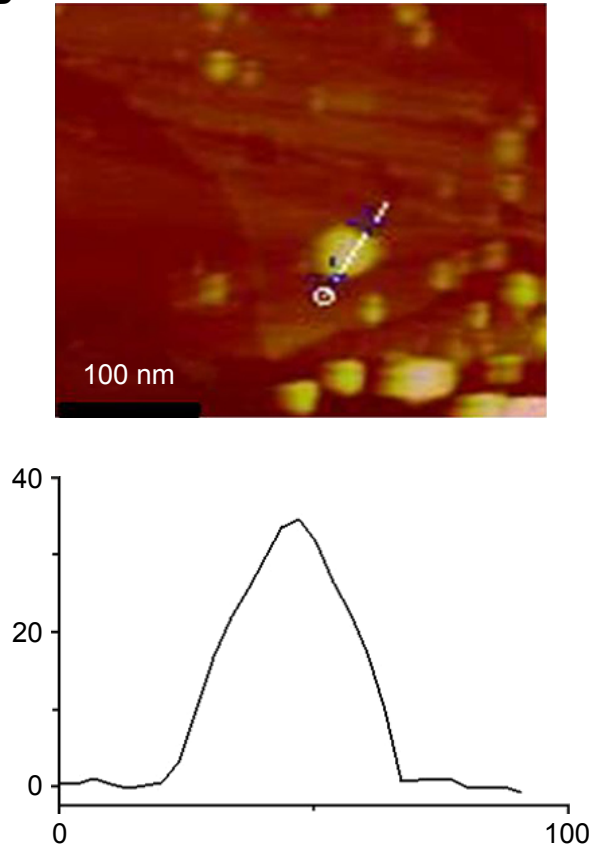

Figure S4 AFM images of GO (A) and GO/GNPs (B).

Abbreviations: AFM, atomic force microscope; GNPs, gold nanoparticles; GO, graphene oxide.

A

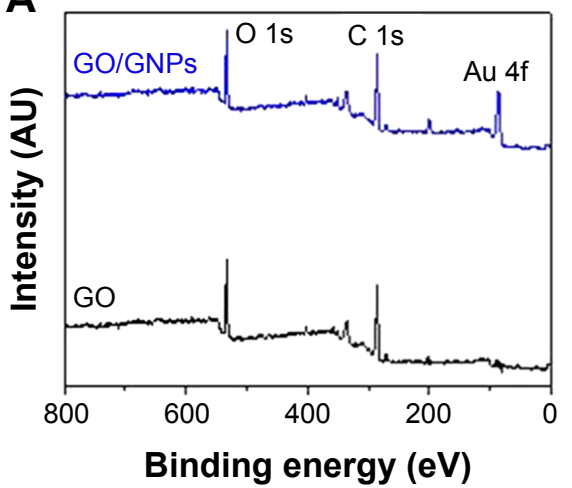

C

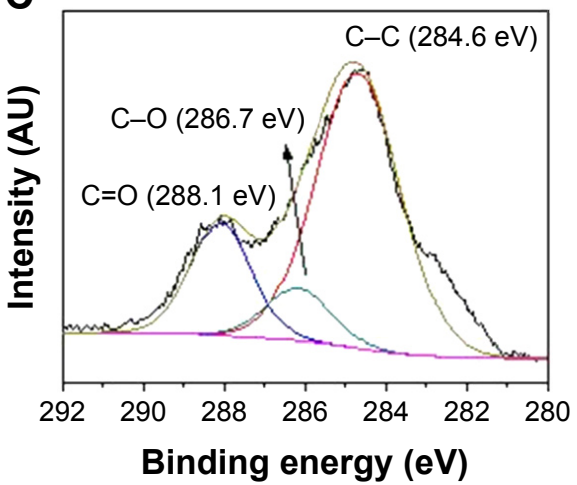

B

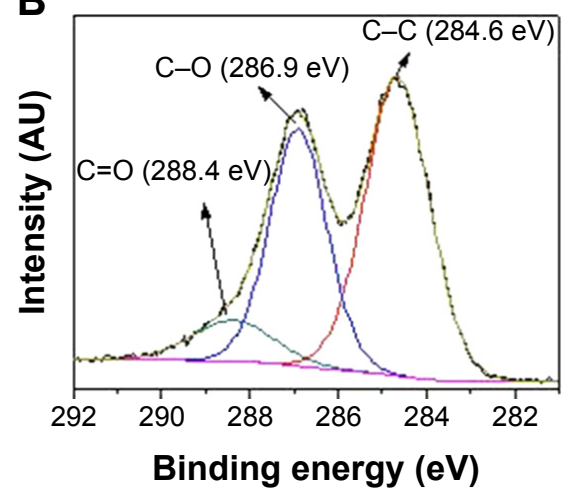

D

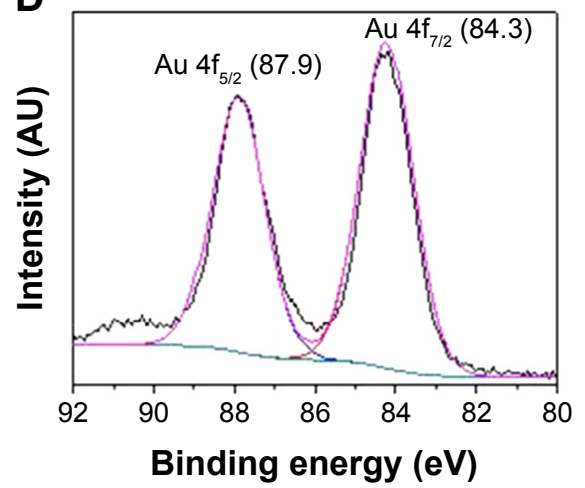

Figure S5 XPS spectra of GO and GO/GNPs.

Notes: (A) Full XPS scan spectra of GO and GO/GNPs. (B) C Is spectra of GO. (C) C Is spectra of GO/GNPs. (D) Au 4f spectra of GO/GNPs.

Abbreviations: GNPs, gold nanoparticles; GO, graphene oxide; XPS, X-ray photoelectron spectroscopy. 


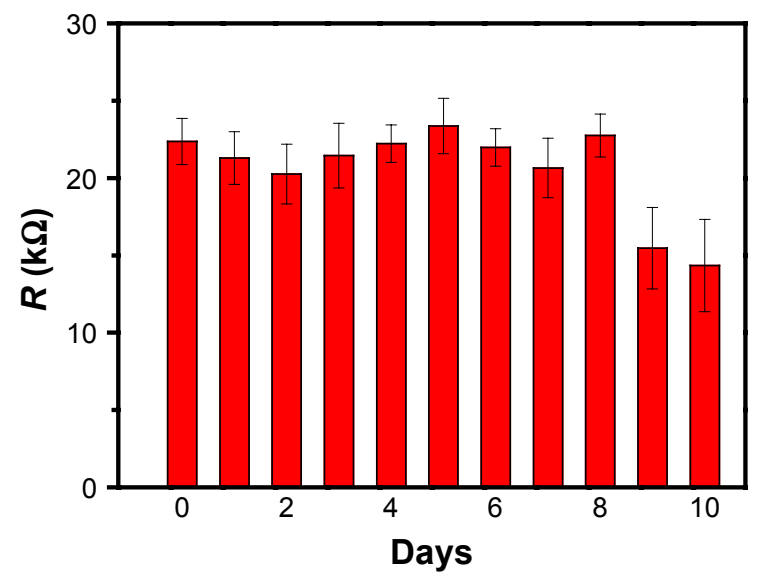

Figure $\mathbf{S 6}$ The resistance of GO/GNPs hydrogel at 0-10 days. Abbreviations: GNPs, gold nanoparticles; GO, graphene oxide.

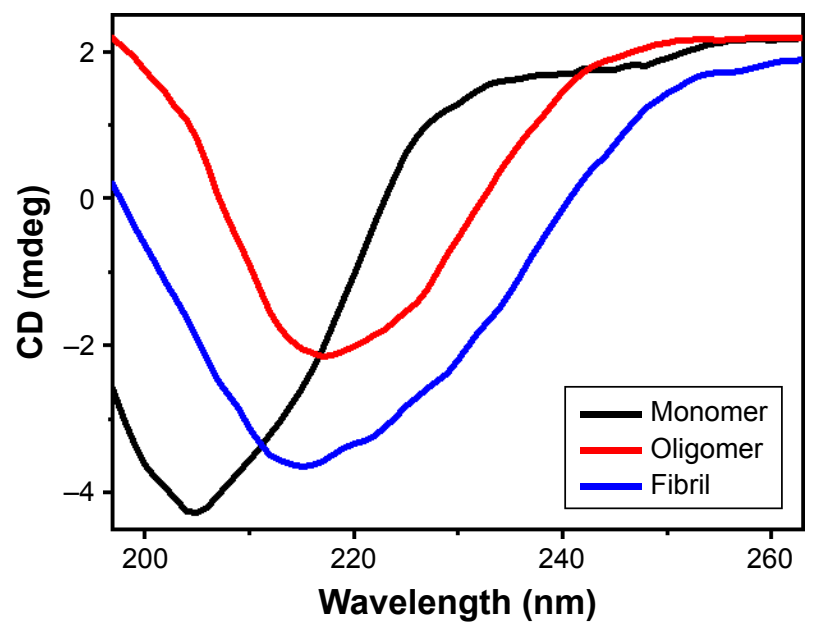

Figure S7 CD spectra of $A \beta_{1-42}$ monomers, oligomers and fibrils. Abbreviations: $A \beta$, amyloid-beta; $C D$, circular dichroism.

Table SI Secondary structures of $A \beta_{1-42}$ monomers, oligomers, and fibrils

\begin{tabular}{llll}
\hline Fraction & Ratio (\%) & & Oligomers \\
\cline { 2 - 4 } & Monomers & 45.44 & 13.56 \\
\hline$\alpha$-Helix & 10.78 & 27.92 & 68.37 \\
$\beta$-Sheet & 13.05 & 26.64 & 18.07 \\
Random coil & 76.17 & &
\end{tabular}

Abbreviation: $A \beta$, amyloid-beta.
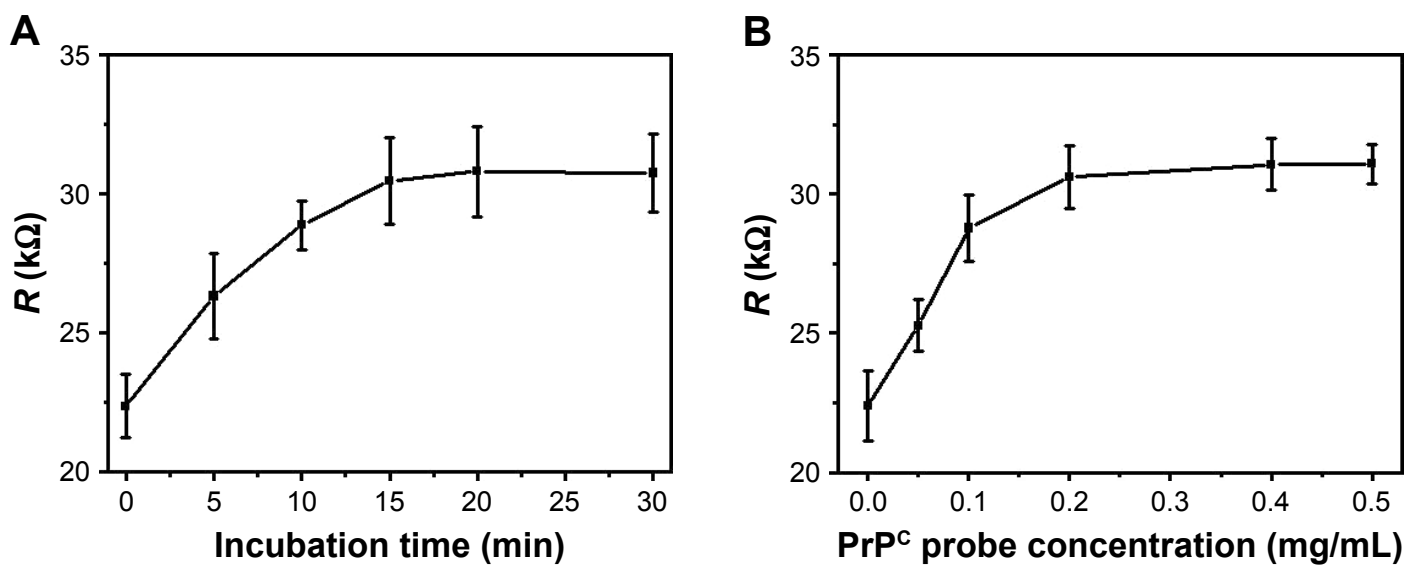

Figure S8 (A) The effect of the incubation time of PrPC probe on the electron-transfer resistance of the GO/GNPs hydrogel electrode. The PrPC probe concentration was $2 \mathrm{mg} / \mathrm{mL}$. (B) The effect of the PrPC probe concentration on the resistance of the electrode. The electrode was incubated with PrPC probe for 15 min. $R$ : electron-transfer resistance. The error bars indicate standard deviation $(n=3)$.

Abbreviations: GNPs, gold nanoparticles; GO, graphene oxide; PrPC, cellular prion protein. 
A

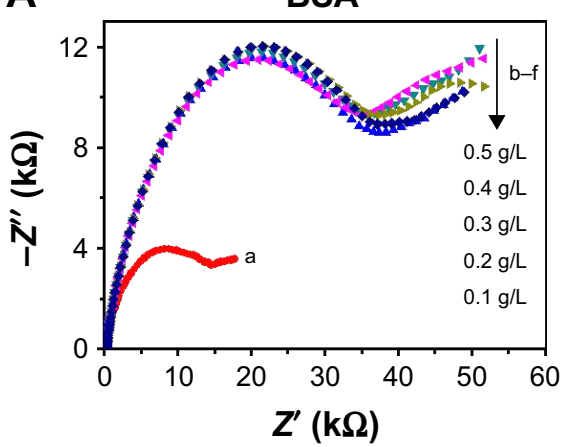

B

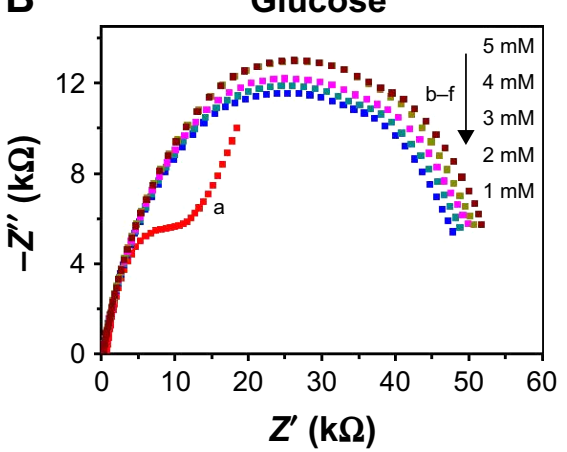

C

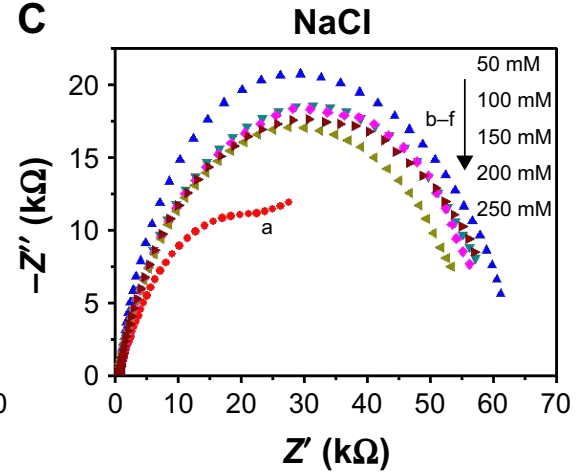

Figure $\mathbf{S 9}$ Influences of $\mathrm{BSA}$, glucose, and $\mathrm{NaCl}$ on $\mathrm{A} \beta \mathrm{O}$ detection.

Notes: The GO/GNPs-PrPC biosensor was used to detect I nM aßO at $0.1-0.5 \mathrm{~g} / \mathrm{L} \mathrm{BSA}(\mathbf{A}), \mathrm{I}-5 \mathrm{mM}$ glucose (B), and $50-250 \mathrm{mM} \mathrm{NaCl}(\mathbf{C})$. Curve a represents the control experiment without BSA, glucose, or $\mathrm{NaCl}$. Curves $b-f$ represent the effects of different concentrations of the disturbing substance on the impedance of the biosensor. Abbreviations: $A \beta O$, amyloid-beta oligomers; BSA, bovine serum albumin; GNPs, gold nanoparticles; GO, graphene oxide.

Table S2 Performances of $\mathrm{A} \beta \mathrm{O}$ detection methods based on $\mathrm{PrPC}^{\mathrm{C}}$ probe

\begin{tabular}{llll}
\hline Methods & Detection limit & Linear range & References \\
\hline Electrochemical impedance spectra & $0.5 \mathrm{pM}$ & $\mathrm{I} \mathrm{pM}-1 \mu \mathrm{M}$ & $\mathrm{I}$ \\
Linear-sweep voltammetry & $8 \mathrm{pM}$ & $20 \mathrm{pM}-100 \mathrm{nM}$ & 2 \\
Electrochemical-chemical-chemical redox cycling & $0.2 \mathrm{pM}$ & $5 \mathrm{pM}-0.2 \mathrm{nM}$ & 3 \\
Electrochemical impedance spectra & $45 \mathrm{pM}$ & $0.1 \mathrm{nM}-0.2 \mathrm{M}$ & 4 \\
Linear sweep voltammetry & $6 \mathrm{pM}$ & $0.01 \mathrm{nM}-200 \mathrm{nM}$ & 5,6 \\
Colorimetry & $0.5 \mathrm{nM}$ & $0.001 \mu \mathrm{M}-0.5 \mu \mathrm{M}$ & \\
Fluorescence & $0.2 \mathrm{nM}$ & $0.5 \mathrm{nM}-0.1 \mu \mathrm{M}$ & \\
Fluorescence & $1 \mathrm{nM}$ & $10 \mathrm{nM}-2 \mathrm{mM}$ & \\
\hline
\end{tabular}

Abbreviations: $\mathrm{A} \beta \mathrm{O}$, amyloid-beta oligomers; $\mathrm{PrP}^{\mathrm{C}}$, cellular prion protein.

\section{References}

1. Rushworth JV, Ahmed A, Griffiths HH, Pollock NM, Hooper NM, Millner PA. A label-free electrical impedimetric biosensor for the specific detection of Alzheimer's amyloid-beta oligomers. Biosens Bioelectron. 2014;56:83-90.

2. Xia N, Wang X, Zhou B, Wu Y, Mao W, Liu L. Electrochemical detection of amyloid- $\beta$ oligomers based on the signal amplification of a network of silver nanoparticles. ACS Appl Mater Interfaces. 2016;8(30):19303-19311.

3. Xia N, Liu L, Wu R, et al. Ascorbic acid-triggered electrochemicalchemical-chemical redox cycling for design of enzyme-amplified electrochemical biosensors on self-assembled monolayer-covered gold electrodes. J Electroanal Chem. 2014;731:78-83.

4. Xia N, Wang X, Yu J, et al. Design of electrochemical biosensors with peptide probes as the receptors of targets and the inducers of gold nanoparticles assembly on electrode surface. Sens Actuat B Chem. 2017;239:834-840.
5. Xing Y, Feng XZ, Zhang L, Hou J, Han GC, Chen Z. A sensitive and selective electrochemical biosensor for the determination of beta-amyloid oligomer by inhibiting the peptide-triggered in situ assembly of silver nanoparticles. Int J Nanomedicine. 2017;12:3171-3179.

6. Xia N, Zhou B, Huang N, Jiang M, Zhang J, Liu L. Visual and fluorescent assays for selective detection of beta-amyloid oligomers based on the inner filter effect of gold nanoparticles on the fluorescence of CdTe quantum dots. Biosens Bioelectron. 2016;85:625-632.

7. Liu L, Xia N, Zhang J, et al. A graphene oxide-based fluorescent platform for selective detection of amyloid- $\beta$ oligomers. Anal Methods. $2015 ; 7: 8727-8732$.
International Journal of Nanomedicine

\section{Publish your work in this journal}

The International Journal of Nanomedicine is an international, peerreviewed journal focusing on the application of nanotechnology in diagnostics, therapeutics, and drug delivery systems throughout the biomedical field. This journal is indexed on PubMed Central, MedLine, CAS, SciSearch ${ }^{\circledR}$, Current Contents ${ }^{\circledR} /$ Clinical Medicine,

\section{Dovepress}

Journal Citation Reports/Science Edition, EMBase, Scopus and the Elsevier Bibliographic databases. The manuscript management system is completely online and includes a very quick and fair peer-review system, which is all easy to use. Visit http://www.dovepress.com/ testimonials.php to read real quotes from published authors. 